Article

\title{
Differentiating Soils from Arable and Fallow Land Using Spectrometry
}

\author{
Pavel Ukrainskiy ${ }^{1}$ (), Fedor Lisetskii ${ }^{2, *(1)}$ and Arseniy Poletaev ${ }^{1}$ (I) \\ 1 Federal-Regional Centre of Aerospace and Surface Monitoring of the Objects and Natural Resources, \\ Belgorod State National Research University, 308015 Belgorod, Russia; ukrainski@bsu.edu.ru (P.U.); \\ poletaev@bsu.edu.ru (A.P.) \\ 2 Institute of Earth Sciences, Belgorod State National Research University, 308015 Belgorod, Russia \\ * Correspondence: liset@bsu.edu.ru
}

Citation: Ukrainskiy, P.; Lisetskii, F.; Poletaev, A. Differentiating Soils from Arable and Fallow Land Using Spectrometry. Soil Syst. 2021, 5, 54. https://doi.org/10.3390/ soilsystems 5030054

Academic Editor:

Megharaj Mallavarapu

Received: 30 July 2021

Accepted: 26 August 2021

Published: 1 September 2021

Publisher's Note: MDPI stays neutral with regard to jurisdictional claims in published maps and institutional affiliations.

Copyright: (c) 2021 by the authors. Licensee MDPI, Basel, Switzerland. This article is an open access article distributed under the terms and conditions of the Creative Commons Attribution (CC BY) license (https:/ / creativecommons.org/licenses/by/ $4.0 /)$.

\begin{abstract}
In this study, we analyse soil system responses-in particular, the colours of soils resulting from different types of land use (arable land and residential areas) caused by the construction of an ancient boundary rampart near a multilayer monument dating from between prehistory and the Middle Ages within the boundaries of the Bosporus Kingdom (Eastern Crimea) - in an area of modern and ancient (4th-2nd centuries BC) land use (Northwestern Crimea). These differences are of interest because they offer the chance to decipher different types of ancient land use and systems of land surveying, incorporating data from colour aerial photographs obtained with the help of unmanned aerial vehicles. Soil samples displaying different types of anthropogenic transformation were taken from the ancient boundary ramparts and adjacent land. The soil colour coordinates in the CIE $L^{*} a * b$ system were measured with the help of an AvaSpec-2048 spectrometer. Differences in colour coordinates were analysed using analysis of variance (NPMANOVA) based on the permutation test, the Kruskal-Wallis test, and the Mann-Whitney test, corrected according to multiple comparisons carried out as per the Bonferroni method. The results of this statistical analysis show that there are statistically significant differences in soil colour coordinates between samples collected on the ramparts and under various other types of land use. These differences are more pronounced in the samples characterised by the agrogenic transformation of soil. This makes it possible to use remote sensing data to detect traces of ancient boundary ramparts, even if the ramparts are partially destroyed by ploughing.
\end{abstract}

Keywords: color measurements; soil color; CIE L*a*b; Crimean Peninsula; ancient agricultural territory; land use planning

\section{Introduction}

Ancient land demarcation systems have been some of the most interesting objects for soil and archaeological research in Crimea. Until now, traces of ancient boundary ramparts that divided land plots in ancient times have remained intact on modern arable land. Mapping such objects is the primary stage of the study conducted by [1]. For the Crimean Peninsula, experience was accumulated in the use of remote sensing data to search for and map ancient boundary ramparts in zones of antique agriculture. For this purpose, photographic images from American satellites of the CORONA series were used [2-4]. As these images were panchromatic, the image texture and contrast of brightness of objects were key features for recognising the boundary ramparts. Today, aerial photography from unmanned aerial vehicles (UAVs) has become a promising technique for the remote mapping of ancient boundary ramparts. The colour of objects is key for the detection of boundary ramparts according to these data. The soil colour is a useful integral indicator, as it is determined by the complex of the results of pedogenesis, such as organic matter, carbonates, clay minerals, quartz oxides of iron, manganese, and water-soluble salts [5-9]. 
The use of colour as a deciphering feature was based on ground level and laboratory research. Experience in such studies had been accumulated previously in connection with the use of multi-spectral satellite images of low and medium spatial resolution. This experience was based on laboratory spectrometric measurements and was subsequently implemented in deciphering images [10-14]. Laboratory colourimetric measurements play the same role for aerial imagery produced by UAVs.

It is known that a soil's colour is related to its properties [15]. There are estimates of the quantitative relationship between colour coordinates and various soil characteristics, including those obtained for the soils of semi-arid regions [16-19]. To distinguish ancient boundary ramparts, it is necessary to investigate the degree and nature of the differences in colour coordinates between the ancient man-made ramparts and surrounding territory, which includes two types of fallow land (an ancient land plot and a zone with a cultural layer). A part of the ancient zones of antique agriculture in Crimea is currently not ploughed up and represents ancient fallow lands. This allows for the determination of how modern ploughing affects the ability to distinguish ancient ramparts and land plots according to the soil colour. The objective of the present study is to compare the colour coordinates of the soil sampled on ancient ramparts depending on different types of land use (agrogenesis and residential areas). This is the first use of such research for the territories of ancient agriculture in Crimea. Colourimetric measurements can be another useful tool in this, along with geochemical data, remote sensing, and satellite positioning technologies.

\section{Study Area}

In addition to the ancient ramparts widely represented in Crimea in the land cadastre, sometimes, there are rampart fences between agricultural landscapes and residential areas, both in the Bosporus [20,21] and in northwestern Crimea [4,22]. Soil was sampled during field trips for the measurement of colour at two sites on the territory on the Crimean Peninsula (Figure 1). Our research included both types of ramparts: (1) a rampart in the ancient land management system (Figure 1B (plot 1)) and (2) a rampart fence (Figure $1 \mathrm{C}$ (plot 2)). Two transects were laid at each site. One of the pair of transects passed along the boundary rampart, and the other ran in parallel to it on the ancient land plot. Thirty samples were taken at each transect. To measure soil colour during field trips, samples were taken (from a depth of $5-10 \mathrm{~cm}$ in fallow lands and $0-10 \mathrm{~cm}$ in arable land). The coordinates of sampling were recorded with the use of a Garmin Oregon GPS receiver. A total of 120 samples were taken from the soil surface. The samples were dried to an air-dry condition and milled to a powdered state.

The first site is located in the Saksky district of the Republic of Crimea, $15 \mathrm{~km}$ north-east of Yevpatoriya (the ancient town of Kerkinitis). The features of this site have been described earlier [23], starting from the time of antique land use (4-2 c. BC) [24] and up to the formation of multi-aged fallow lands. According to the results of the interpretation of aerial and satellite images, this region had three types of ancient land management (orthogonal, irregular, and the so-called "long fields") [22]. The latter type of land management was characterised by the division of land into plots with a width of 41-42 $\mathrm{m}$ using boundary ramparts up to $20 \mathrm{~cm}$ high, but which were not used to create transverse boundaries in allotments. It is one of such boundary ramparts and the adjacent old arable land plot that became the objects of soil research. The surviving signs of land surveying make it possible to define the 4th-2nd centuries BC as a time of agrarian prehistory in land use [23]. According to remote sensing, the land plot near the rampart was used for arable land, with a gap in 2012-2018. The arable horizon has a dark yellowish-brown colour (10YR $4 / 4)$ and is characterised by a medium alkaline reaction of the soil solution ( $\mathrm{pH}$ is 8.3 ), a low Corg content of $0.93 \%$, and a high content of mobile phosphorus and exchangeable potassium. Presently, these lands are periodically ploughed up and used for the cultivation of crops. At the time of the soil sampling, the fields were fallow. The length of each transect was $550 \mathrm{~m}$. The distance between transects was $5 \mathrm{~m}$, and along the transect, the distance between sampling points varied from 5 to $8 \mathrm{~m}$. 


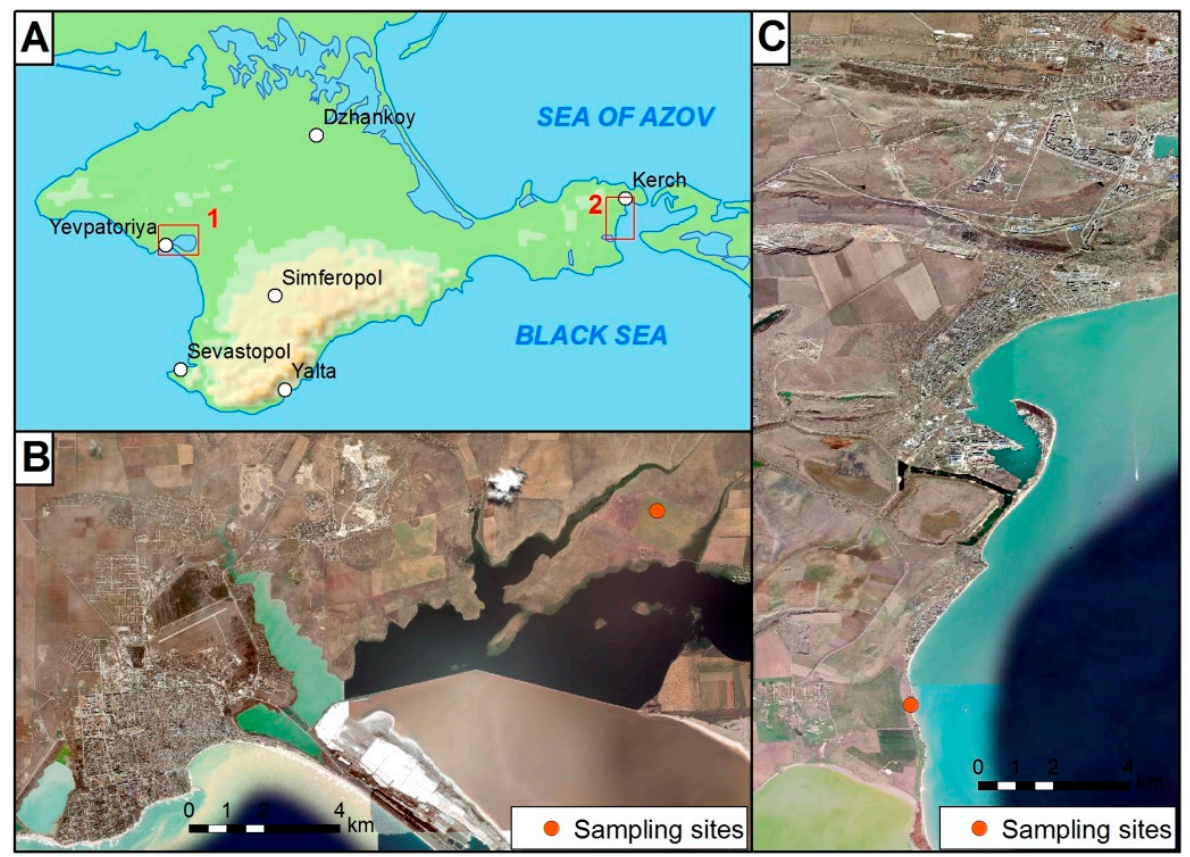

Figure 1. Study area: the first site (15 km north-east of the ancient town of Kerkinitis) and second site (16 km south the ancient town of Bosporos, near the Geroevka-2 settlement) (A), soil sampling location on the first site (B), soil sampling location on the second site (C). Satellite imagery mosaic source-ESRI World Imagery.

The second site is located $16 \mathrm{~km}$ south of Kerch (near the Geroevka-2 settlement). The Geroevka-2 settlement is located $3 \mathrm{~km}$ from the antique city of Nympheus and occupies an area of about 4 hectares in terms of the distribution of the cultural layer [20]. Its residential, economic, and burial complexes belong to four chronological periods: antique (the turn of the 6th-5th centuries BC, 2nd and 3rd quarters of the 4th century BC) and early medieval (4th-6th and 8th-9th centuries AD). As the artefacts (dated pottery fragments) are multilayered, the rampart fence, which is functionally connected to them, could be created in a wide chronological range. The method of pedogenetic chronology was used for dating the rampart by the thickness of horizons $\mathrm{A}+\mathrm{AB}$ at its top. This area is presently not ploughed up and is covered with natural steppe vegetation. Thus, it represents postagrogenic fallow land. The length of each transect was $140 \mathrm{~m}$. The distance between the transects was $30 \mathrm{~m}$, and the distance between sampling points along the transect varied from 15 to $20 \mathrm{~m}$. As per satellite images, the surviving length of the boundary rampart is $233 \mathrm{~m}$, and its width varies from 3 to $7 \mathrm{~m}$.

Plot 58: In a series of soil profile cuts around the archaeological excavation at the Geroevka-2 settlement, we found virgin soil at the southern flank of the excavation, which, according to the morphological structure, is closest to the zone standard (virgin soil). This virgin land is southern medium loamy black earth on loess-like loam (the thickness of horizon $\mathrm{A}$ is $38 \mathrm{~cm}$; $\mathrm{A}+\mathrm{AB}$ is $63 \mathrm{~cm}$; and in the layer $89-131 \mathrm{~cm}$, there is a horizon of accumulation of new carbonate formations). In this region, the thickness of the humus horizon in virgin soil is usually $61-67 \mathrm{~cm}$.

Plot 56: The soil sampling point is located $12 \mathrm{~m}$ west of the rampart top. According to the satellite imagery data collected in 1984 and 1988, the site was ploughed up. Since 2005, it has represented continuous postagrogenic fallow land. In 2011, there was a fire. The vegetation is feather grass (Stipa capillata $\mathrm{L}$.) with $100 \%$ projective cover. The litter thickness is $1 \mathrm{~cm}$. A thatch layer of $0-4.5 \mathrm{~cm}$ thickness has formed within the soil.

Plot 57: The soil sampling point is located $7.5 \mathrm{~m}$ east of the rampart top. The vegetation is feather grass (Stipa capillata L.) with $95 \%$ projective cover. The litter thickness is $1 \mathrm{~cm}$. A thatch layer of $0-5.2 \mathrm{~cm}$ thickness has formed within the soil. Fragments of amphorae were found on the surface, and smaller ceramic pieces occur in the profile. 


\section{Materials and Methods}

Chemical analyses of soils included the following standard procedures [25]: a determination of the Corg content by Tyurin's method (oxidation of the organic substance with a solution of $\mathrm{K}_{2} \mathrm{Cr}_{2} \mathrm{O}_{7}$ in sulphuric acid (GOST 26213-91)); measurement of $\mathrm{pH}$ by the potentiometric method ( $\mathrm{pH}$ meter: Sartorius Basic Meter PB-11); measurement of the alkaline hydrolysable nitrogen according to the Cornfield method; measurement of the available $\mathrm{P}_{2} \mathrm{O}_{5}\left(\mathrm{mg} \mathrm{kg}^{-1}\right)$ by Machigin's method (spectrophotometer UNICO-1200, USA, 2012); and measurement of $\mathrm{K}_{2} \mathrm{O}$ on a Fiery photometer. Total nitrogen $(\mathrm{N})$ was estimated by Kjeldahl's procedure (GOST P 58596-2019. The determination of cation exchange capacity (CEC) in calcareous soils was performed using EDTA-Na 2 (GOST 17.4.4.01-84). A wavelength-dispersion X-ray fluorescence spectrometer (Spectroscan Max-GV) was used to determine the contents of chemical elements. The concentrations of 24 metals and oxides in soils (macroelements $\left(\mathrm{SiO}_{2}, \mathrm{CaO}, \mathrm{TiO}_{2}, \mathrm{MnO}, \mathrm{MgO}, \mathrm{Fe}_{2} \mathrm{O}_{3}, \mathrm{Al}_{2} \mathrm{O}_{3}, \mathrm{Na}_{2} \mathrm{O}, \mathrm{P}_{2} \mathrm{O}_{5}\right.$, and $\mathrm{K}_{2} \mathrm{O}$ ) and trace elements $(\mathrm{Co}, \mathrm{Ni}, \mathrm{Cu}, \mathrm{Cr}, \mathrm{Zn}, \mathrm{Zr}, \mathrm{Pb}, \mathrm{V}, \mathrm{Rb}, \mathrm{Sr}, \mathrm{Ba}, \mathrm{S}, \mathrm{Cl}$, and $\mathrm{As})$ ) were determined by measuring the fractions of metal mass and oxides in powdered samples. Soil colours were described using the Munsell system [26].

A previously created regional pedochronological database [27] made it possible to use the chronofunction of the dependence of the thickness of the humus horizon of soils on time for dating the age of the soil on anthropogenic surfaces (the top of the boundary rampart) [28]. Soil sampling was carried out along two pairs of parallel transects. One pair was laid on modern arable land (Yevpatoriya region) and the other on fallow land (Kerch region). In each pair, one transect passed along the ancient boundary rampart, and the other ran on the land plot. Measurement of the soil colour was carried out in laboratory conditions [29] using a hardware-software complex from Avantes, which included the following:

- $\quad$ spectrometer AvaSpec-2048;

- $\quad$ standard light source AvaLight-DHc;

- bifurcation fiber optic cable;

- $\quad$ standard white WS-2;

- a computer with AvaSoft 8.10 full installed, including the AvaSoft-COL module.

In measurements, a $2^{\circ}$ viewing angle was used. The height above the sample was $5 \mathrm{~cm}$. Colour coordinates were determined in the 1976 version of the CIE L*a*b system [30-33]. The measurements were carried out three times for each soil sample. Subsequently, according to these measurements, the average values of the colour coordinates were calculated. The obtained data were processed and visualised using the $R$ 3.4.4 [34] programming language in RStudio 1.1.453 integrated development environment [35].

Statistical analysis consisted of three consecutive stages: multivariate analysis of variance, analysis of variance, and multiple pairwise comparisons. Transition to a new stage of the analysis was conducted if statistically significant results were obtained in the previous stage. As some of the samples had a distribution differing from the norm, non-parametric statistical tests were used: non-parametric multivariate analysis of variance (NPMANOVA) based on the permutation test [36], the Kruskal-Wallis analysis of variance [37], and the Mann-Whitney test [38] corrected according to multiple comparisons carried out as per the Bonferroni method [39]. To carry out the first test, an additional package (version 2.5-6) [40] was used. The second and third tests were performed with standard R tools. For the Kruskal-Wallis analysis of variance, the kruskal.test function was used. For the MannWhitney test, the pairwise.wilcox.test function was used.

To justify the need for a non-parametric technique of multivariate analysis of variance, the Doornik-Hansen test from the MVN package (version 5.8) was used [41,42]. For NPMANOVA performance, the adonis2 function was used where the test variant based on the principles described by McArdle and Anderson was implemented [43]. NPMANOVA was carried out with the use of Euclidean distance and 999 permutations. 


\section{Results and Discussion}

As can be seen from the transverse profile of the rampart (Figure 2B), soil has formed in its upper part, with the total thickness of the horizons $\mathrm{A}+\mathrm{AB}$ being $428 \pm 15 \mathrm{~mm}$ $(n=12)$. Using the method of pedogenetic chronology [28], the time the rampart was built west of the Geroevka-2 settlement can be linked to the beginning of its functioning in the 6th century BC.

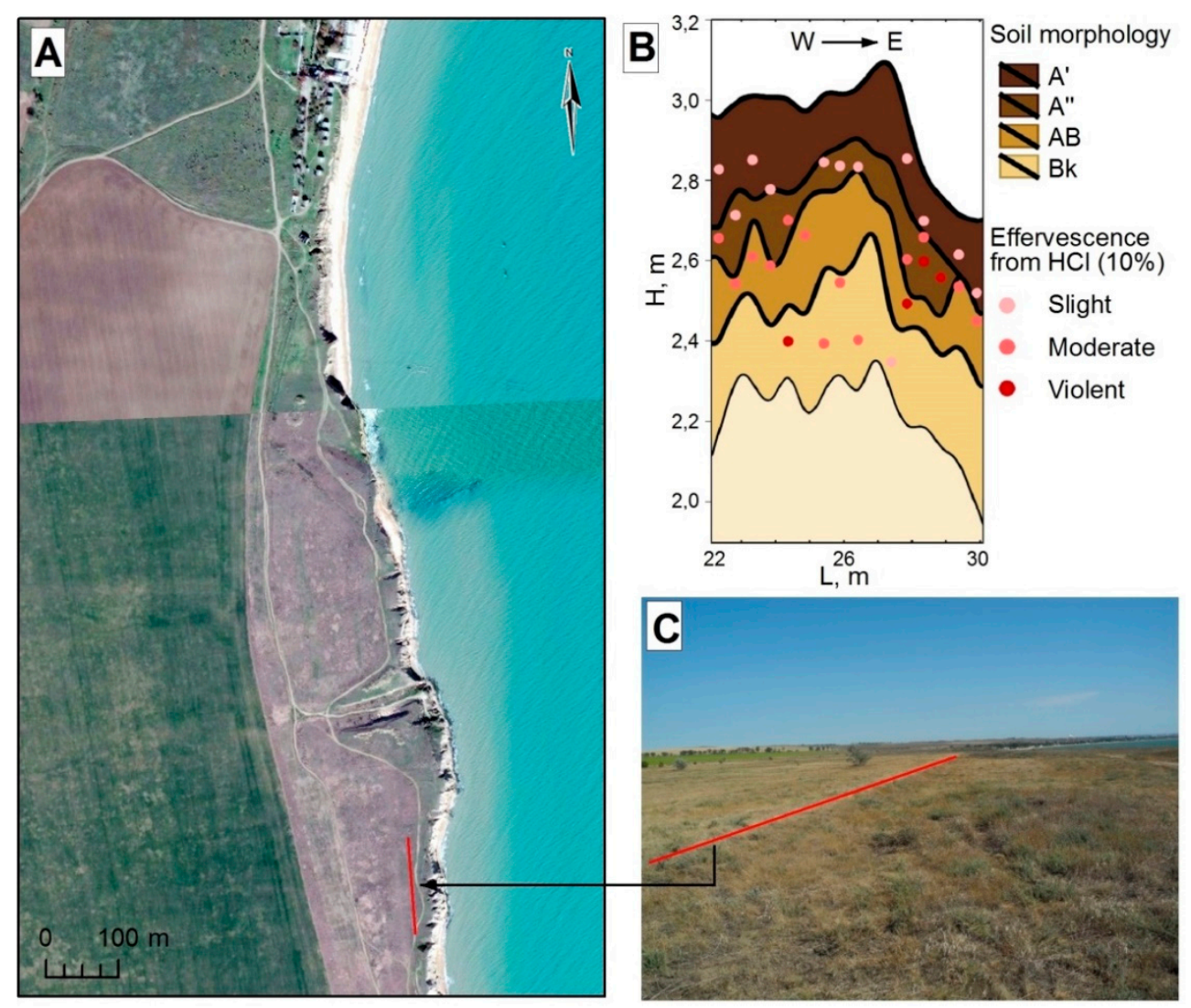

Figure 2. Location (A), current state of the boundary rampart (B), and transverse profile of the rampart (C) near the Geroevka-2 settlement. Satellite imagery mosaic source-ESRI World Imagery.

The upper part of horizon A for the soil, which functioned for 15 years as postagrogenic land (plot 56), differs from the virgin analogue with the depletion of the content of Corg and mobile nitrogen, but has a higher bulk density (Table 1). The soil, which formed on the cultural layer of the multilayer settlement (plot 57), occupies an intermediate position between the virgin analogue and postagrogenic land according to its physicochemical properties.

A number of anthropogenic soil transformations are expressed by 24 macroelements, as well as trace elements characterising the differences in eight other elements. The postagrogenic soil contains less $\mathrm{Cl}, \mathrm{Na}$, and $\mathrm{S}$ than virgin soil because of its distance from the sea, but the higher content of $\mathrm{Cu}$ and $\mathrm{As}$ can be associated with the influence of agrotechnical loads. Places of human activity (postresidential soil) are reflected in the upper part of horizon A only by a higher content of arsenic, while the content of heavy metals is higher in non-turbocharged soil located directly near the residential zone of the rural settlement.

The postagrogenic fallow (to the west of the boundary rampart) contains higher concentrations of $\mathrm{CaO}, \mathrm{Cu}$, and $\mathrm{Pb}$ in comparison with the soil to the east of the rampart, but a lower content of $\mathrm{Na}, \mathrm{S}$, and As. The ploughing results did not affect the change in the concentration of such oxides and elements such as $\mathrm{TiO}_{2}, \mathrm{MnO}, \mathrm{Fe}_{2} \mathrm{O}_{3}, \mathrm{~K}_{2} \mathrm{O}, \mathrm{Cr}, \mathrm{Ni}, \mathrm{Rb}$, $\mathrm{Sr}$, and Ba. 
Table 1. Physicochemical and geochemical properties of the upper part of horizon A.

\begin{tabular}{|c|c|c|c|}
\hline No Plot & 56 & 57 & 58 \\
\hline Depth $(\mathrm{cm})$ & $4.5-17$ & $5.2-17$ & $5-17$ \\
\hline Bulk density $\left(\mathrm{g} \mathrm{cm}^{-3}\right)$ & 1.30 & 0.96 & 1.06 \\
\hline Munsell color (dry) & 10YR 4/2.5 & 10YR 4/2.5 & 10YR $4 / 3$ \\
\hline Humus (\%) & 2.5 & 3.0 & 3.9 \\
\hline $\mathrm{P}_{2} \mathrm{O}_{5}\left(\mathrm{mg} \cdot \mathrm{kg}^{-1}\right)$ & 8 & 7 & 16 \\
\hline $\mathrm{K}_{2} \mathrm{O}\left(\mathrm{mg} \cdot \mathrm{kg}^{-1}\right)$ & 417 & 455 & 599 \\
\hline $\mathrm{pH}\left(\mathrm{H}_{2} \mathrm{O}\right)$ & 8.1 & 8.1 & 8.2 \\
\hline $\mathrm{pH}(\mathrm{KCl})$ & 7.1 & 7.0 & 7.1 \\
\hline Total nitrogen $(\%)$ & 0.20 & 0.20 & 0.28 \\
\hline $\begin{array}{l}\text { Soil cation exchange, } \\
\left(\mathrm{cmol}(+) \mathrm{kg}^{-1}\right)\end{array}$ & 28.2 & 28.4 & 28.8 \\
\hline Hydrolysable $\mathrm{N}\left(\mathrm{mg} \cdot \mathrm{kg}^{-1}\right)$ & 105 & 119 & 140 \\
\hline $\mathrm{Cl}\left(\mathrm{mg} \cdot \mathrm{kg}^{-1}\right)$ & 78.4 & 77.2 & 168.5 \\
\hline $\mathrm{Na}_{2} \mathrm{O}(\%)$ & 0.9 & 1.4 & 1.4 \\
\hline $\mathrm{S}\left(\mathrm{mg} \cdot \mathrm{kg}^{-1}\right)$ & 560.4 & 613.6 & 775.5 \\
\hline $\mathrm{Pb}\left(\mathrm{mg} \cdot \mathrm{kg}^{-1}\right)$ & 18.1 & 15.6 & 28.2 \\
\hline $\mathrm{P}_{2} \mathrm{O}_{5}(\%)$ & 0.22 & 0.21 & 0.26 \\
\hline $\mathrm{Zn}\left(\mathrm{mg} \cdot \mathrm{kg}^{-1}\right)$ & 60.5 & 62.5 & 66.9 \\
\hline As $\left(\mathrm{mg} \cdot \mathrm{kg}^{-1}\right)$ & 17.7 & 19.7 & 14.1 \\
\hline $\mathrm{Cu}\left(\mathrm{mg} \cdot \mathrm{kg}^{-1}\right)$ & 33.0 & 26.1 & 27.1 \\
\hline
\end{tabular}

For the research site near the settlement of Geroyevka 2, statistically significant differences in colour coordinates between the land plots located on opposite sides of the rampart fence (west of the rampart (postagrogenic soil) and east of the rampart (never-ploughed adjacent territory)) were found. According to the results of the Mann-Whitney test, for the colour coordinate $\mathrm{L}^{*}$, criterion $\mathrm{U}=11.0$ at $p=6.60 \times 10^{-15}$; for the colour coordinate $\mathrm{a}^{*}$, criterion $\mathrm{U}=1.0$ at $p=6.76 \times 10^{-17}$; and for the colour coordinate $\mathrm{b}^{*}$, criterion $\mathrm{U}=870.0$ at $p=3.38 \times 10^{-17}$.

In our study, after the measurement of the colour of the soil samples, a three-dimensional visualisation of their position in the colour space CIE $1976\left(\mathrm{~L}^{*} \mathrm{a}^{*} \mathrm{~b}^{*}\right)$ was carried out (Figure 3).

The set of points corresponding to the samples forms a specific structure in the CIE $1976\left(\mathrm{~L}^{*} \mathrm{a}^{*} \mathrm{~b}^{*}\right)$ space. First, the points are divided into two clouds that do not intersect and are noticeably distant from one another. These two clouds correspond to soil samples taken from modern arable land and on the steppe (i.e., on the ancient fallow land). Here, the cloud of points corresponding to the arable land is larger. Visually, the samples from the arable land have a greater scattering of colour coordinates in the CIE $1976\left(\mathrm{~L}^{*} \mathrm{a} * \mathrm{~b}\right)$ space than the samples from the steppe. The second feature of the structure of the analysed data was the presence in each of the point clouds of two components, which are close to one another, but almost do not intersect. These parts of the point clouds correspond to the samples taken from the boundary rampart and plot. Thus, the resulting visualisation of the soil sample's position in the three-dimensional space of colour coordinates shows that all four samples can be distinguished from one another by colour. The leading factor in the determination of the colour of the samples is the type of modern land use (arable land or steppe). The transect type (along the rampart or on the ancient plot) has far less influence. Conclusions drawn based on the visual analysis of the soil samples' position in the colour space are supported by the results of quantitative analysis (Tables 2-5). 


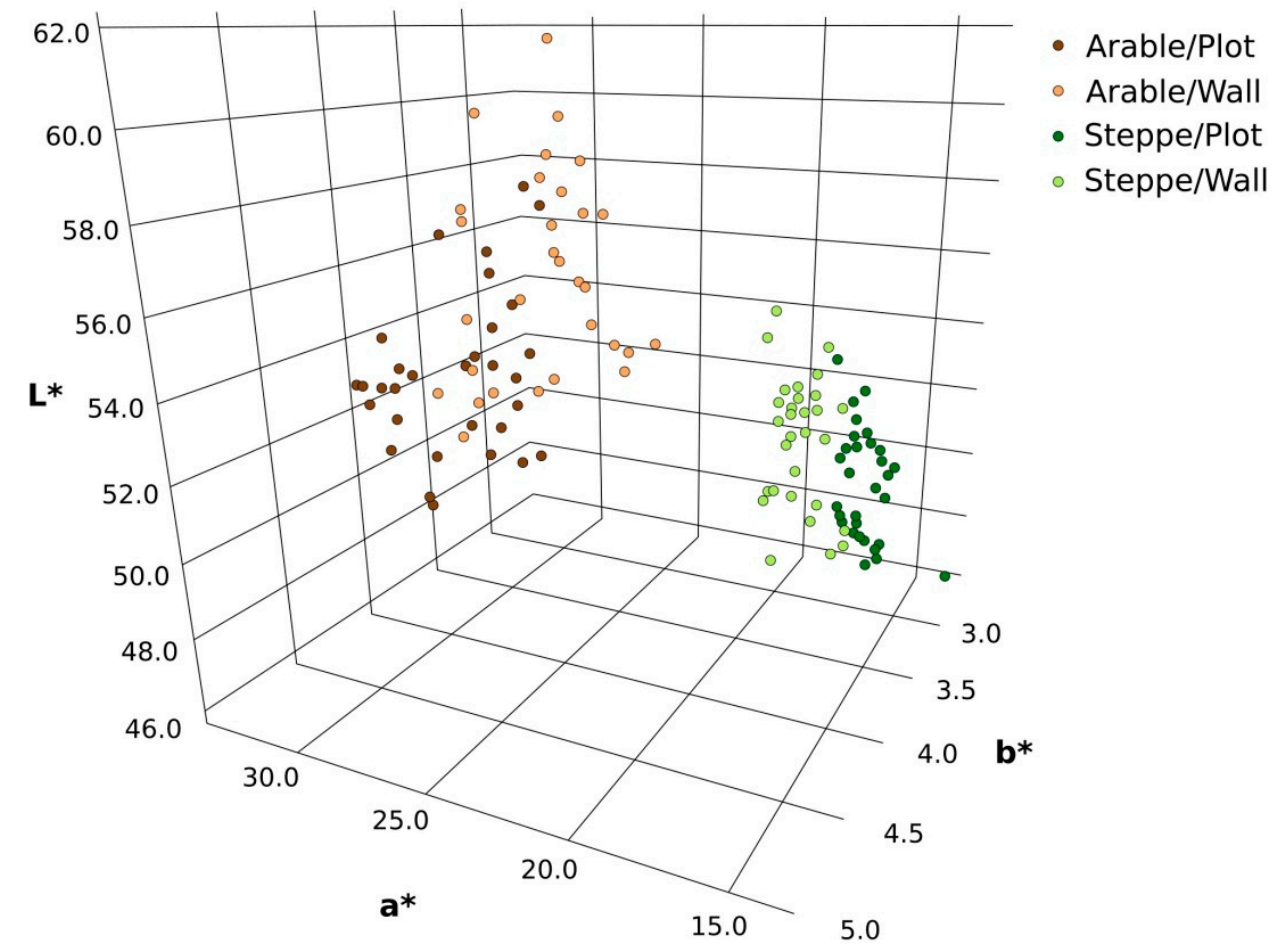

Figure 3. Position of soil samples in color space CIE $1976\left(\mathrm{~L}^{*} \mathrm{a}^{*} \mathrm{~b}^{*}\right)$.

Table 2. Descriptive statistics for color coordinate values.

\begin{tabular}{lccccc}
\hline \multicolumn{1}{c}{ Sample } & Minimum & Mean & Median & Maximum & Standard Deviation \\
\hline Arable/Plot & 50.76 & 53.52 & 52.91 & 58.57 & 2.01 \\
\hline Arable/Wall & 51.59 & 56.69 & 56.82 & 61.81 & 2.59 \\
\hline Steppe/Plot & 46.12 & 50.41 & 50.49 & 54.37 & 1.75 \\
\hline Steppe/Wall & 47.52 & 51.13 & 51.64 & 55.15 & 2.01 \\
\hline & & & $\mathbf{a}^{*}$ & \\
\hline Arable/Plot & 3.79 & 4.13 & 4.11 & 4.61 & 0.19 \\
\hline Arable/Wall & 3.88 & 4.37 & 4.43 & 4.93 & 0.19 \\
\hline Steppe/Plot & 2.65 & 3.32 & 3.33 & 3.62 & 0.13 \\
\hline Steppe/Wall & 3.00 & 3.23 & 3.25 & 3.47 & 2.65 \\
\hline & & & $\mathbf{b}^{*}$ & & 2.86 \\
\hline Arable/Plot & 25.03 & 28.47 & 27.41 & 33.28 & 0.55 \\
\hline Arable/Wall & 21.06 & 23.53 & 21.98 & 29.30 & 0.70 \\
\hline Steppe/Plot & 13.67 & 15.71 & 15.69 & 16.47 & 19.52 \\
\hline Steppe/Wall & 17.12 & 18.49 & 18.76 & & \\
\hline
\end{tabular}


Table 3. Results of nonparametric multivariate analysis of variance (NPMANONA).

\begin{tabular}{cccccc}
\hline Variable $^{*}$ & df & Sums of Squares & $\mathbf{R}^{\mathbf{2}}$ & $\mathbf{F}$ & $\boldsymbol{p}$-Value \\
\hline $\mathrm{L}$ & 1 & 2964.60 & 0.65 & 388.39 & 0.001 \\
$\mathrm{~T}$ & 1 & 148.80 & 0.03 & 17.54 & 0.001 \\
$\mathrm{~L} / \mathrm{T}$ & 1 & 492.50 & 0.11 & 58.04 & 0.001 \\
Residuals & 116 & 984.30 & 0.21 & & \\
Total & 119 & 4590.20 & 1.00 & &
\end{tabular}

${ }^{*} \mathrm{~L}$ is land use type (arable land and steppe), $\mathrm{T}$ is transect type (wall and plot), and L/T is interaction between land use type and transect type.

Table 4. Kruskal-Wallis test results.

\begin{tabular}{cccc}
\hline Color Coordinate & $\mathbf{H}$ & $\mathbf{d f}$ & $\boldsymbol{p}$-Value \\
\hline $\mathrm{L}^{*}$ & 71.02 & 3 & $2.58 \times 10^{-15}$ \\
$\mathrm{a}^{*}$ & 94.11 & 3 & $<2.20 \times 10^{-16}$ \\
$\mathrm{~b}^{*}$ & 105.99 & 3 & $<2.20 \times 10^{-16}$ \\
\hline
\end{tabular}

Table 5. Results of pairwise comparisons of mean values of color coordinates using the MannWhitney test ( $p$-values corrected by the Bonferroni method).

\begin{tabular}{|c|c|c|c|}
\hline & Arable/Wall & Arable/Plot & Steppe/Wall \\
\hline \multicolumn{4}{|c|}{$\mathbf{L}^{*}$} \\
\hline Arable/Plot & $1.20 \times 10^{-5}$ & - & - \\
\hline Steppe/Wall & $1.00 \times 10^{-11}$ & 0.0002 & - \\
\hline Steppe/Plot & $5.20 \times 10^{-14}$ & $1.00 \times 10^{-6}$ & 0.76 \\
\hline \multicolumn{4}{|c|}{$\mathbf{a}^{*}$} \\
\hline Arable/Plot & 0.002 & - & - \\
\hline Steppe/Wall & $1.80 \times 10^{-10}$ & $1.80 \times 10^{-10}$ & - \\
\hline Steppe/Plot & $1.80 \times 10^{-10}$ & $1.80 \times 10^{-10}$ & 0.06 \\
\hline \multicolumn{4}{|c|}{$\mathbf{b}^{*}$} \\
\hline Arable/Plot & $1.60 \times 10^{-5}$ & - & - \\
\hline Steppe/Wall & $1.80 \times 10^{-10}$ & $1.80 \times 10^{-10}$ & - \\
\hline Steppe/Plot & $<2.20 \times 10^{-16}$ & $1.80 \times 10^{-10}$ & $1.80 \times 10^{-10}$ \\
\hline
\end{tabular}

The values taken for each colour coordinate are shown in Table 1 for all four samples separately. The largest scattering of values, in terms of the standard deviation value, is observed at the $\mathrm{L}^{*}$ coordinate, which shows the degree of lightness. Chromatic coordinates $\left(a^{*}\right.$ and $b^{*}$ ) vary to a lesser extent. It is characteristic that the standard deviation of the colour coordinates of the samples collected on the rampart is higher than in the samples collected on the plot. The only exception is the $\mathrm{a}^{*}$ coordinate for the samples taken from the steppe.

If the samples are compared by dividing them into two groups (arable land and steppe), then all colour coordinates of the samples collected on the arable land are, on average, higher than those of the samples from the steppe (Table 2, Figure 4). The arable soil is lighter (the $\mathrm{L}^{*}$ coordinate is higher), redder (the $\mathrm{a}^{*}$ coordinate is higher), and more yellow (the $b^{*}$ coordinate is higher). 

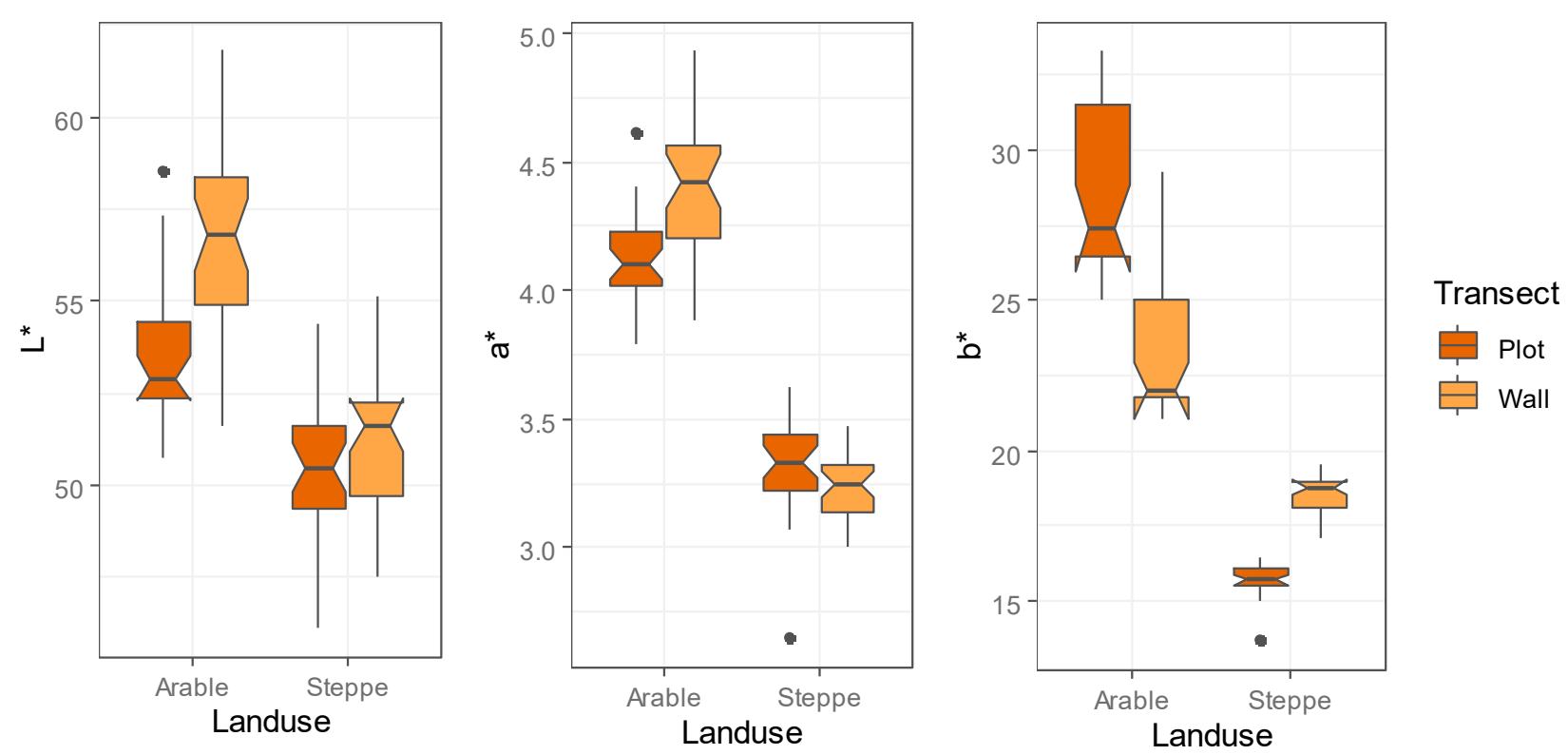

Figure 4. Boxplots of color coordinates of soil samples in the CIE $1976\left(\mathrm{~L}^{*} \mathrm{a}^{*} \mathrm{~b}^{*}\right)$ color space.

In the arable territory, the average values of all colour coordinates of the samples taken from the rampart and plot differ more strongly than in the soil underlying the steppe vegetation (Table 2, Figure 3). On average, samples collected on the rampart are lighter than those collected on the plot (i.e., they have a higher $\mathrm{L}^{*}$ value). For the chromatic component of the colour space (coordinates $\mathrm{a}^{*}$ and $\mathrm{b}^{*}$ ), the differences are not so unidirectional. The $a^{*}$ coordinate is higher for the samples taken from the rampart. On the contrary, on the steppe, the $\mathrm{a}^{*}$ coordinate is higher for the samples taken from the plot. The $\mathrm{b}^{*}$ coordinate on arable land is higher on the plot, and on the steppe, it is higher on the rampart.

In the quantitative analysis of the differences in colour coordinates between samples, we considered colour coordinates as a set of dependent variables. These dependent variables correlate with one another. For coordinates $L^{*}$ and $a^{*}$, we used Spearman's correlation coefficient $\rho=0.77$ at $p=6.59 \times 10^{-24}$; for coordinates $\mathrm{L}^{*}$ and $\mathrm{b}^{*}$, Spearman's correlation coefficient $\rho=0.56$ at $p=1.03 \times 10^{-10}$; and for coordinates $\mathrm{a}^{*}$ and $\mathrm{b}^{*}$, Spearman's correlation coefficient $\rho=0.67$ at $p=4.37 \times 10^{-17}$ ( $p$-values are obtained with the Bonferroni correction). The analysis of the colour coordinate set for the multivariate normality of distribution using the Doornik-Hansen test showed that the value of the criterion $\mathrm{E}$ was equal to 120.81 at $p=1.10 \times 10^{-23}$, i.e., distribution of the set of dependent variables significantly differs from the multivariate normal distribution according to statistics.

The correlation of dependent variables introduces the need for a multivariate analysis of variance. For the data studied, a multivariate analysis of variance is needed to precede a series of unilabiate ANOVAs performed for each of the dependent variables separately. As the condition of multivariate normality for the dependent variables was not satisfied, a multivariate analysis of variance with the use of non-parametric methods needed to be carried out.

The results of the non-parametric multivariate analysis of variance (Table 3 ) show that the values for the set of colour coordinates (coordinates $\mathrm{L}^{*}, \mathrm{a}^{*}$, and $\mathrm{b}^{*}$ ) are influenced by both the type of land (arable land or fallow land) and the type of transect (along the rampart or on the plot). In addition, colour coordinates are influenced by the interaction between two dependent variables. The influence of all three variables is statistically significant $(p<0.05)$, but not the same. The strength of the influence of factors is characterised by the value of $R^{2}$. Based on its value, we can conclude that the influence of the type of land use is many times greater (about 20 times greater) than the influence of the type of transect. This is consistent with the distance between point clouds that we can observe in Figure 3. 
The results of the non-parametric analysis of variance according to Kruskal-Wallis analysis (Table 4) show that the sample group (Arable/Plot, Arable/Wall, Steppe/Plot, Steppe/Wall) affects the colour of soil samples. For all colour coordinates, the Kruskal-Wallis test results are statistically significant $(p<0.05)$. Thus, for each colour coordinate, there is at least one pair of sample groups whose medians are statistically significantly different.

The Mann-Whitney test with pairwise comparisons (Table 5) showed which of the pairs of samples had statistically significant differences in colour coordinates and which did not. Such differences are found in the majority of compared pairs. They are not found in the values of coordinates $\mathrm{L}^{*}$ and $\mathrm{a}^{*}$ in samples collected from the rampart and plot in the steppe. In these cases, the $p$-values exceed 0.05 .

It should be noted that the obtained $p$-values are highly dependent on the correction used for multiple comparisons. We used the most conservative correction for multiple comparisons: the Bonferroni correction. When the Holm correction [44] was used, the differences in the $\mathrm{a}^{*}$ coordinates for samples collected from the rampart and plot in the steppe were statistically significant at $p=0.01$.

In the future, the results can be obtained using other instruments, including in the field. Although modern instruments for soil colour evaluation (spectrophotometers, spectroradiometers, and photocolourimeters) are used [10,13], digital devices (cameras) [5,8] and flatbed scanners are more accessible to researchers $[6,45,46]$. In this case, a constant artificial light source is used, or the photograph is taken in natural light, but using calibration scales. RGB values extracted from a photo can be converted to XYZ (RGB to XYZ) and then to CIE-L*a*b* [47].

\section{Conclusions}

Laboratory colourimetric measurements have shown that there are differences between the soil colour of ancient land plots and boundary ramparts. These differences are statistically significant. The lightness of the soil (colour coordinate $\mathrm{L}^{*}$ ) differs to a greater extent, and the chromatic colour coordinates (coordinates $a^{*}$ and $b^{*}$ ) differ to a lesser extent. Ploughing up ancient fallow lands formed on the sites of ancient agriculture leads to a change in the soil colour. The change in soil colour is associated with the loss of humus during agricultural use. This causes lightening. Compared with the ancient fallow land, one can see that the average values of the colour coordinates on arable land change, and the dispersion of their values increases. However, the nature of the colour differences between the boundary rampart and plot is maintained. In addition, the value of these differences increases. The results obtained suggest that ancient boundary ramparts can be detected according to the soil colour based on aerial photography from unmanned aerial vehicles. Detection according to colour can be successful even if the ancient ramparts, because of ploughing, cannot be distinguished in the relief.

Author Contributions: Conceptualization, F.L.; methodology, F.L. and P.U.; software, P.U.; formal analysis, P.U.; investigation, F.L.; data curation, A.P. and P.U.; writing-original draft preparation, F.L. and P.U.; writing — review and editing, F.L.; visualization, P.U. and A.P.; supervision, F.L.; project administration. All authors have read and agreed to the published version of the manuscript.

Funding: This research received no external funding.

Institutional Review Board Statement: Not applicable.

Informed Consent Statement: Not applicable.

Acknowledgments: The authors acknowledge Tatyana Smekalova from Research Centre of History and Archaeology of Crimea for archaeological consultations. We would also like to thank anonymous reviewers and an academic editor for their valuable comments and suggestions that helped us in improving this paper.

Conflicts of Interest: The authors declare no conflict of interest. 


\section{References}

1. Smekalova, T.N.; Terekhin, E.A.; Pasumanskiy, A.E.; Lisetskii, F.N. Using of historical cartography, remote sensing data and GIS for studying of land division system of Taurian Chersonesos. InterCarto InterGIS 2020, 26, 177-187. [CrossRef]

2. Trelogan, J.; Crawford, M.; Teng, L.; Kwon, O.; Carter, J. Mapping the features of the chora of Chersonesos via remotely sensed data. In Proceedings of the IEEE 1999 International Geoscience and Remote Sensing Symposium (IGARSS'99), Hamburg, Germany, 28 June-2 July 1999; Stein, T.I., Ed.; IEEE: New York, NY, USA, 1999; Volume 5, pp. 2569-2571.

3. Carter, J.C.; Crawford, M.; Lehman, P.; Nikolaenko, G.; Trelogan, J. The Chora of Chersonesos in Crimea, Ukraine. Am. J. Archaeol. 2000, 104, 707-741. [CrossRef]

4. Stolba, V.F.; Andresen, J. Unveiling the hinterland: A new type of Hellenistic rural settlement in Crimea. Antiquity 2015, 89, 345-360. [CrossRef]

5. Viscarra Rossel, R.A.; Fouad, Y.; Walter, C. Using a digital camera to measure soil organic carbon and iron contents. Biosyst. Eng. 2008, 100, 149-159. [CrossRef]

6. Bulygin, S.Y.; Bidolakh, D.I.; Lisetskii, F.N. Assessment of soil humus content using their digistal images. Nauch. Ved. Belgorod. Gos. Univ. Ser. Estestv. Nauki. 2011, 16, 154-159.

7. Pérez, F.L. Plant organic matter really matters: Pedological effects of kūpaoa (dubautia menziesii) shrubs in a volcanic alpine area, Maui, Hawai'i. Soil Syst. 2019, 3, 31. [CrossRef]

8. Kirillova, N.P.; Zhang, Y.; Hartemink, A.E.; Zhulidova, D.A.; Artemyeva, Z.S.; Khomyakov, D.M. Calibration methods for measuring the color of moist soils with digital cameras. Catena 2021, 202, 105274. [CrossRef]

9. Schmidt, S.A.; Ahn, C. Analysis of soil color variables and their relationships between two field-based methods and its potential application for wetland soils. Sci. Total Environ. 2021, 783, 147005. [CrossRef] [PubMed]

10. Demattê, J.A.; Campos, R.C.; Alves, M.C.; Fiorio, P.R.; Nanni, M.R. Visible-NIR reflectance: A new approach on soil evaluation. Geoderma 2004, 121, 95-112. [CrossRef]

11. Bellinaso, H.; Demattê, J.A.M.; Romeiro, S.A. Soil spectral library and its use in soil classification. Rev. Bras. Ciência Solo 2010, 34, 861-870. [CrossRef]

12. Summers, D.; Lewis, M.; Ostendorf, B.; Chittleborough, D. Visible near-infrared reflectance spectroscopy as a predictive indicator of soil properties. Ecol. Indic. 2011, 11, 123-131. [CrossRef]

13. Gholizadeh, A.; Amin, M.S.M.; Borůvka, L.; Saberioon, M.M. Models for estimating the physical properties of paddy soil using visible and near infrared reflectance spectroscopy. J. Appl. Spectrosc. 2014, 81, 534-540. [CrossRef]

14. Gore, R.D.; Chaudhari, R.H.; Gawali, B.W. Creation of Soil Spectral Library for Marathwada Region. Int. J. Adv. Remote Sens. GIS 2016, 5, 1787-1794. [CrossRef]

15. Konen, M.E.; Burras, C.L.; Sandor, J.A. Organic carbon, texture, and quantitative color measurement relationships for cultivated soils in north central Iowa. Soil Sci. Soc. Am. J. 2003, 67, 1823-1830. [CrossRef]

16. Sánchez-Marañón, M.; Delgado, G.; Melgosa, M.; Hita, E.; Delgado, R. CIELAB color parameters and their relationship to soil characteristics in Mediterranean red soils. Soil Sci. 1997, 162, 833-842. [CrossRef]

17. Gunal, H.; Ersahin, S.; Yetgin, B.; Kutlu, T. Use of chromameter-measured color parameters in estimating color-related soil variables. Commun. Soil Sci. Plant Anal. 2008, 39, 726-740. [CrossRef]

18. Ibáñez-Asensio, S.; Marqués-Mateu, A.; Moreno-Ramón, H.; Balasch, S. Statistical relationships between soil colour and soil attributes in semiarid areas. Biosyst. Eng. 2013, 116, 120-129. [CrossRef]

19. Moreno-Ramón, H.; Marqués-Mateu, Á.; Ibáñez-Asensio, S. Significance of soil lightness versus physicochemical soil properties in semiarid areas. Arid Land Res. Manag. 2014, 28, 371-382. [CrossRef]

20. Zinko, V.N. Geroevka-2. A rural settlement in the chora of Nimphaion (Ancient period). Archeol. Warshawa 1997, XLVII, 35-94.

21. Zubarev, V.G.; Smekalov, S.L. Map of archaeological sites tracts Adzhiel in the eastern Crimea, according to different sources. Mod. Appl. Sci. 2014, 9, 184-191. [CrossRef]

22. Lisetskii, F.; Stolba, V.; Golyeva, A.; Marinina, O.; Poletaev, A. Postantique soils as a source of land use information: A case study of an ancient Greek agricultural area on the Northern Black Sea Coast. Appl. Environ. Soil Sci. 2020, 2020, 8698179. [CrossRef]

23. Lisetskii, F.N.; Poletaev, A.O.; Terekhin, E.A.; Marinina, O.A. Soil-genetic differences of multi-aged fallow lands in an ancient agricultural region of steppe Crimea. IOP Conf. Ser. Earth Environ. Sci. 2021, 817, 012061. [CrossRef]

24. Smekalova, T.N.; Kutaisov, V.A. Role of Chersonessian polis in the development of north-west Tauris in Hellenistic time. Strat. Plus 2018, 3, 353-370.

25. Arinushkina, E.V. Manual on the Chemical Analysis of Soils; 1970. Available online: https://agris.fao.org/agris-search/search.do? recordID=US201300468313 (accessed on 31 August 2021).

26. Munsell, A. Munsell Soil Color Charts; Revised Edition; Gretag Macbeth: New Windsor, NY, USA, 1994.

27. Lisetskii, F. Estimates of soil renewal rates: Applications for anti-erosion arrangement of the agricultural landscape. Geosciences 2019, 9, 266. [CrossRef]

28. Lisetskii, F.N.; Stolba, V.F.; Goleusov, P.V. Modeling of the evolution of steppe Chernozems and development of the method of pedogenetic chronology. Eurasian Soil Sci. 2016, 49, 846-858. [CrossRef]

29. Torrent, J.; Barrón, V. Laboratory measurement of soil color: Theory and practice. In Soil Color; SSSA Special Publications; SSSA: Madison, WI, USA, 1993; Volume 31, pp. 21-33. [CrossRef]

30. Robertson, A.R. The CIE 1976 color-difference formulae. Color Res. Appl. 1977, 2, 7-11. [CrossRef] 
31. Ohno, Y. CIE fundamentals for color measurements. In International Conference on Digital Printing Technologies, Vancouver, Canada, 16-20 October 2000; Society for Imaging Science and Technology: Springfield, IL, USA, 2000; pp. 540-545.

32. Rossel, R.V.; Minasny, B.; Roudier, P.; Mcbratney, A.B. Colour space models for soil science. Geoderma 2006, 133, 320-337. [CrossRef]

33. Vodyanitskii, Y.N.; Kirillova, N.P. Application of the CIE-L*a*b* system to characterize soil color. Eurasian Soil Sci. 2016, 49, 1259-1268. [CrossRef]

34. R Core Team. R: A Language and Environment for Statistical Computing; R Foundation for Statistical Computing: Vienna, Austria, 2021. Available online: https:/ / www.R-project.org/ (accessed on 20 July 2021).

35. Racine, J.S. RStudio: A platform-independent IDE for R and Sweave. J. Appl. Econom. 2012, 27, 167-172. [CrossRef]

36. Anderson, M.J. A new method for non-parametric multivariate analysis of variance. Austral Ecol. 2001, 26, 32-46. [CrossRef]

37. Kruskal, W.H.; Wallis, W.A. Use of ranks in one-criterion variance analysis. J. Am. Stat. Assoc. 1952, 47, 583-621. [CrossRef]

38. Mann, H.B.; Whitney, D.R. On a test of whether one of two random variables is stochastically larger than the other. Ann. Math. Stat. 1947, 18, 50-60. [CrossRef]

39. Wright, S.P. Adjusted P-Values for Simultaneous Inference. Biometrics 1992, 48, 1005-1013. [CrossRef]

40. Oksanen, J.; Blanchet, F.G.; Friendly, M.; Kindt, R.; Legendre, P.; McGlinn, D.; Minchin, P.R.; O'Hara, R.B.; Simpson, G.L.; Solymos, P.; et al. Vegan: Community Ecology Package. R Package Version 2.5-4. 2019. Available online: https://CRAN.R-project.org/ package= vegan (accessed on 20 July 2021).

41. Doornik, J.A.; Hansen, H. An Omnibus test for univariate and multivariate normality. Oxf. Bull. Econ. Stat. 2008, 70, 927-939. [CrossRef]

42. Korkmaz, S.; Goksuluk, D.; Zararsiz, G. MVN: An R Package for Assessing Multivariate Normality. R J. 2014, 6, 151-162. [CrossRef]

43. McArdle, B.H.; Anderson, M.J. Fitting multivariate models to community data: A comment on distance-based redundancy analysis. Ecology 2001, 82, 290-297. [CrossRef]

44. Holm, S. A simple sequentially rejective multiple test procedure. Scand. J. Stat. 1979, 6, 65-70.

45. Valeeva, A.A.; Aleksandrova, A.B.; Koposov, G.F. Color estimation of forest-steppe soils by digital photography under laboratory conditions. Eurasian Soil Sci. 2016, 49, 1033-1037. [CrossRef]

46. Kirillova, N.P.; Kemp, D.B.; Artemyeva, Z.S. Colorimetric analysis of soil with flatbed scanners. Eur. J. Soil Sci. 2017, 68, 420-433. [CrossRef]

47. Kirillova, N.P.; Sileva, T.M. Colorimetric analysis of soils using digital cameras. Mosc. Univ. Soil Sci. Bull. 2017, 72, 13-20. [CrossRef] 